\title{
The evaluation of possibilities of modern level casting bindings on the technological lignin basis practical appliance
}

\author{
Yu.A. Svinoroev ${ }^{1}$, V.V. Dyadichev ${ }^{2 *}, K . A$. Batyshev $^{3}, K . G$. Semenov $^{3}, A . V$. Dyadichev $^{2}$, \\ S.Ye. Chornobay ${ }^{2}$, and S.G. Menyuk ${ }^{2}$ \\ ${ }^{1}$ Kamensky Technological Institute (branch), Platov SRSPU (NPI), Kamensk-Shakhtinsky, Russia \\ ${ }^{2}$ V.I. Vernadsky Crimean Federal University, Simferopol, Russia \\ ${ }^{3}$ Bauman Moscow State Technical University, Moscow, Russia
}

\begin{abstract}
Nowadays the ways of overcoming a problem of resource deficit include rationalization of the existing resource potential. In this respect it is expedient to use the secondary products of vegetable raw material processing due to expansion of lignosulfonate materials application.
\end{abstract}

\section{A problem statement}

The experience of industrial enterprises work shows that technologies based on the resource-saving conceptions [1] will allow obtaining cheaper, environmentally friendly, and consequently competitive castings of high quality [1,2]. Let us consider the sphere of binding materials use as the main component of the technological process of casting manufacture [3]. At the industrial plants, where they are applied as the technology component, i.e. casting manufacture, metallurgy, productions of wood chipboards and wood fiberboards, plywood, in construction industry and automobile industry, it is reasonable to adopt the usage of bindings produced on the basis of inorganic materials [4, $5]$ or vegetable raw materials $[6,7]$.

The absence of such advances in this area leads to the emergence of a range of negative problems: the rise in cost of the final product [8] due to its prime cost increase; the decrease of its competitiveness because of that reason $[1,6,8,9]$; worsening of the ecological situation in the location of such enterprises $[6,10]$; lowering of the industrial safety $[6,10$, $11]$; the growth of occupational diseases $[11,12]$ connected with the use of expensive and environmentally dangerous binding materials on the basis of various synthetic resins [13] and oil bindings $[6,7]$. The use of technological lignins, a large-tonnage waste of the pulpand-paper industry, due to their processing into binding materials [7, 14], which differ from inorganic materials by their high manufacturability at the final stages of casting

\footnotetext{
Corresponding author: author@email.org
} 
manufacture (pliability of casting rods and mould elements, having light knockout and regeneration $[6,7])$, is a promising trend in the development of new binding materials.

\subsection{The objective of the work}

Evaluating the developed ways of improving binding ability of lignosulfonate (LST) bindings [7], it is reasonable to consider the practical aspects of their application in the casting manufacturing processes as the tool for improving the resource efficiency of the casting technology.

\section{Materials and the results of the research}

The most significant ways of improving LST binding ability, from the point of view of their successful usage in the casting manufacturing processes, is their modification by nonionic SAS and mechano-activation.

The obtained results $[6,7]$ give the opportunity to broaden the application of LST due to its advantages with the consequent positive effects; however the practical appliance requires doing the adaptation work which will include:

- the evaluation of casting technology, where expensive and dangerous synthetic resins and oil bindings are used, for the purpose of their substitution for lignosulfonate materials processed according to the suggested algorithms;

- the development of the mixture compositions for these technologies and their practical testing instead of the existing ones for the purpose of providing the required quality level;

- the optimization of casting processes' parameters, where the binding material on the LST basis is "built into";

- doing the experimental-industrial tests under the foundry conditions, the correction of the manufacturing procedures' content (setting the working areas and assembly of disintegrating machineries, determining and "provision" of the modifier input spots during their usage, etc.);

- the development of the technical requirements for the application of mixture compositions with LST NSAS instead of mixtures with oil and resin materials.

The most important stage is the first one, listed above, as it sets the rest actions and the obtained results. The content of this stage work will include:

- the comparison of strength characteristics of the bindings (LST and the applied one);

- the economical grounds for the reasonability of application according to all the aspects of the manufacturing process (manufacturability, economy, qualities, ecological compatibility, the change of working conditions, etc.).

Estimating the level of the obtained results and the set of the existing technology of binding materials appliance, as well as considering the specificity of lignosulfonate materials, which consists in the fact that this binding is on the water basis, requiring thermal influence for hardening, it is reasonable to analyze the whole "coordinate system: the LST abilities - the technology of molding-sand preparation" (Table 1).

A consolidated evaluation of the possibilities of LST with improved strength properties practical appliance in the casting manufacturing processes is presented in Table 1. It is necessary to mention that nowadays the results of the work are implemented in the cast-iron molded casting manufacturing process; the method of LST modification by nonionic surface active substances (NSAS) is implied. The application of the developed core sand mixture of such type can be used and for small steel casting, the laboratory experiments of the indicators of its strength correspond to the required regulations, however the industrial tests are required. 
The improvement of the composition has to be concentrated on the issues of providing the required thermal stability for guaranteeing the quality of the steel casting.

It is more reasonable to start implementing technologies where LST are traditionally used (technologies of manufacturing rods and moulds hardened by convective drying) for cast-iron casting manufacture. In this case the improvement tendency will be a partial or complete removal of oil bindings of SB or USK type from the technology. It is enough to use the method of LST modification by nonionic SAS.

Let us consider in more details the manufacturing process of getting rods using heat for their hardening. The technology of producing rods in the heating set and by convective drying applies different toxic synthetic resins, oil bindings and their combinations. The disadvantage of this manufacturing process is the necessity of using expensive and very often deficit binding materials which leads to the rise of the cost for core sand mixture. Besides, during the manufacturing rods process a considerable amount of toxic compounds, creating unfavorable sanitary and hygienic working conditions, are emitted into the working space and the environment $[6,15]$. That is why the task of improving the technical and economic as well as sanitary and hygienic characteristics of this technology becomes urgent.

The set problem can be solved in different ways:

- by combining synthetic resins with low-toxic bindings;

- by selection of special catalysts of hot hardening;

- by creating absolutely new low-toxic binding on the basis of modified LST with the properties of resins and oil materials [7].

The first and the second way allow reducing the content of toxic resins in the mixtures a bit, but they do not solve the problem of considerable improvement of sanitary and hygienic working conditions. That is why the creation of low-toxic bindings on the basis of LST with the properties of high-performance bindings is an effective way for solving a complex of problems connected with economy - LST are cheaper, with ecological compatibility LST are cleaner, and with sanitary and hygienic working conditions in the foundries. This offers a prospect of emergence of new generation core sand mixtures, meeting the ecological requirements of the modern production $[10,16]$.

The methods of LST mechano-activation are reasonable to be applied for the improvement of molding sands quality indicators. Mechano-activation leads to the increase of binding ability of LST from 0.4 to $0.9 \mathrm{MPa}$, i.e. twice; this gives an opportunity to use this effect for improving the molding sands compositions, both for the production of castiron and steel casting (Table 2). The experimental compositions of facing molding sands for dry-molding, oriented to the production of small cast-iron molded casting, are developed. LST were processed in the recommended modes of high-energy influences on the disintegrating set UDA 100. The given compositions of the molding sands are used both for the production of grey cast-iron casting, and for the manufacture of steel castings from carbon steel.

The task of the searching experiments was to find out the possibility of applying methods of LST mechano-activation for the optimization of the molding sand composition, and at the same time reducing the content of the "pure" sand due to the increase of reclaim applying. The possibilities of reducing the usage of molding clay and the hardening cycle change were also studied.

The issues of reducing the duration of hardening were also considered; for drying halfmolds on the basic (used in the manufacture) mixture composition this period lasts 4 hours at the temperature of $200-220{ }^{\circ} \mathrm{C}$.

Thus, the application of the LST mechano-activation methods leads to the rationalization of the molding sand composition: the reduction of the amount of "pure" 
molding sand is possible due to the increase of the reclaim part and due to the decrease of molding clay usage twice.

Table 1. The evaluation of the possibilities of LST with improved strength properties practical appliance in the casting manufacturing processes

\begin{tabular}{|c|c|c|c|}
\hline $\begin{array}{l}\text { The technology of } \\
\text { the molding-sand } \\
\text { preparation and } \\
\text { hardening of the } \\
\text { casting rods and } \\
\text { moulds }\end{array}$ & Cast-iron casting & Steel casting & Notes \\
\hline $\begin{array}{l}\text { Technologies of } \\
\text { hardening by } \\
\text { convective drying }\end{array}$ & $\begin{array}{l}\text { 1. The composition of } \\
\text { the core sand mixture } \\
\text { is developed and } \\
\text { implemented in the } \\
\text { production of small } \\
\text { cast-iron molded } \\
\text { casting (modification } \\
\text { method) } \\
\text { 2. The experimental } \\
\text { composition of the } \\
\text { molding sand with a } \\
\text { lower content of SB } \\
\text { binding and an } \\
\text { accelerated hardening } \\
\text { cycle is developed } \\
\text { (mechano-activation } \\
\text { method) }\end{array}$ & $\begin{array}{l}\text { 1. The composition of } \\
\text { the core sand mixture } \\
\text { is developed and } \\
\text { tested for small steel } \\
\text { casting manufacture } \\
\text { (modification } \\
\text { method). } \\
\text { 2. The experimental } \\
\text { composition of the } \\
\text { molding sand with a } \\
\text { lower content of SB } \\
\text { binding and an } \\
\text { accelerated hardening } \\
\text { cycle is developed } \\
\text { (mechano-activation } \\
\text { method) }\end{array}$ & $\begin{array}{l}\text { Ecological effect, the } \\
\text { reduction of harmful } \\
\text { emissions into the } \\
\text { environment, decrease } \\
\text { of casting prime cost } \\
\text { due to the reduction } \\
\text { of SB binding usage }\end{array}$ \\
\hline $\begin{array}{l}\text { Technologies of } \\
\text { hardening in the } \\
\text { heating set }\end{array}$ & $\begin{array}{l}\text { The composition of the } \\
\text { core sand mixture is } \\
\text { developed for the } \\
\text { production of bell's } \\
\text { rods (weighed not } \\
\text { more than } 10 \mathrm{~kg} \text { ) in } \\
\text { manufacturing cast- } \\
\text { iron pressure-water } \\
\text { pipes and sewer pipes } \\
\text { (modification method) }\end{array}$ & $\begin{array}{c}\text { The researches were } \\
\text { not carried out }\end{array}$ & $\begin{array}{l}\text { Ecological effect, the } \\
\text { reduction of harmful } \\
\text { emissions into the } \\
\text { environment, decrease } \\
\text { of casting prime cost } \\
\text { due to the reduction } \\
\text { of carbamide- } \\
\text { formaldehyde resins } \\
\text { (CF-O, CF-MT) usage }\end{array}$ \\
\hline $\begin{array}{l}\text { Technologies of } \\
\text { hardening by hot } \\
\text { gas blowing }\end{array}$ & $\begin{array}{l}\text { The composition of the } \\
\text { core sand mixture is } \\
\text { developed for the } \\
\text { production of bell's } \\
\text { rods (of any weight) in } \\
\text { manufacturing cast- } \\
\text { iron pressure-water } \\
\text { pipes and sewer pipes } \\
\text { (modification method) }\end{array}$ & $\begin{array}{c}\text { The researches were } \\
\text { not carried out }\end{array}$ & $\begin{array}{l}\text { The reduction of } \\
\text { casting prime cost and } \\
\text { the improvement of } \\
\text { the ecological state } \\
\text { due to the usage of } \\
\text { modified LST without } \\
\text { resin binding } \\
\text { application. } \\
\text { Technological } \\
\text { difficulties }\end{array}$ \\
\hline CHM technologies & $\begin{array}{c}\text { The searching } \\
\text { experiments for } \\
\text { molding sands } \\
\text { compositions were } \\
\text { carried out } \\
\text { (modification method) }\end{array}$ & $\begin{array}{c}\text { The searching } \\
\text { experiments for } \\
\text { molding sands } \\
\text { compositions were } \\
\text { carried out } \\
\text { (modification method) }\end{array}$ & $\begin{array}{l}\text { The difficulty of } \\
\text { implementation is the } \\
\text { necessity of using } \\
\text { effective hardeners }\end{array}$ \\
\hline LSM Technologies & $\begin{array}{c}\text { The researches were } \\
\text { not carried out }\end{array}$ & $\begin{array}{c}\text { The researches were } \\
\text { not carried out }\end{array}$ & \\
\hline
\end{tabular}


Table 2. A comparative evaluation of facing molding sands for dry molding on the basis of LST processed by mechano-activation methods

\begin{tabular}{|c|c|c|c|c|}
\hline \multirow{2}{*}{ Composition components: } & \multicolumn{3}{|l|}{ Compositions and quality indicators } \\
\cline { 2 - 5 } & \multicolumn{3}{|l|}{ Experimental compositions } & $\begin{array}{l}\text { Basic mixture } \\
\text { composition, } \\
\text { corresponding quality } \\
\text { indicators }\end{array}$ \\
\cline { 2 - 5 } & $\mathbf{1}$ & $\mathbf{2}$ & $\mathbf{3}$ & 42 \\
\hline $\begin{array}{c}\text { Silica sand of brand 1K02B, } \\
\text { Verkhnedneprovsky, \% }\end{array}$ & 30 & 35 & 40 & 38 \\
\hline $\begin{array}{c}\text { Burnt soil after regeneration, } \\
\%\end{array}$ & 53 & 48 & 43 & $6-8$ \\
\hline Molding clay, \% & 3 & 3 & 3 & $4-8$ \\
\hline LST, \% & 4 & 4 & 4 & 10 \\
\hline Sawdust, \% & 10 & 10 & 10 & $6.0-7.0$ \\
\hline Quality indicator: & & & & 101 \\
\hline Humidity, \% & 6.9 & 6.8 & 6.9 & $0.27-0.33$ \\
\hline Gas permeability,units & 100 & 100 & 100 & $0.33-0.45$ \\
\hline $\begin{array}{c}\text { Strength in the damp state, kg- } \\
\text { force/cm2 }\end{array}$ & 0.25 & 0.27 & 0.31 & 45 \\
\hline Strength in the dry state, MPa & 0.42 & 0.44 & 0.48 & \\
\hline $\begin{array}{c}\text { The duration of drying, min } \\
\text { (at the temperature of 200 }{ }^{\circ} \mathrm{C} \text { ) }\end{array}$ & 30 & 30 & 30 & \\
\hline
\end{tabular}

The duration of drying can be reduced by $20-25 \%$, however for more accurate judgments additional industrial experiments are required.

The presented results allow claiming a potential possibility of applying the method of LST mechano-activation for optimization of molding sand compositions.

An urgent issue is the input of the modifier under dosing it into the LST composition.

The modification variants can be implemented in three ways:

- variant 1 - into the LST storage tank;

- variant 2 - into the accumulation tank in the foundry;

- variant 3 - into the metering device of the chaser mills.

Variant 1 is reasonable to be applied when LST in its full volume has to be used in a modified form. Its disadvantage is the technological inconveniences: during the mixing process it is necessary to adhere to the temperature conditions.

Variant 2 is the most acceptable as in this area it is possible optimally to create the necessary conditions for implementing the modification technology. It is conditioned by the reasonable for technological process implementation capacities (tanks from 400 liters to 2000 liters) and conditions for process implementing - mixing and heating.

Variant 3 is reasonable while implementing the LST modification process by NSAS under conditions of single (repair) production when the manufacturing processes are done on a non-regular basis.

The search for possibilities of implementing the obtained results for preparing CHM and LSM is promising. The searching experiments on creating CHM on the basis of the modificated LST by NSAS demonstrated the perspective of this tendency; however, the difficulties in this case are connected with the search of effective hardeners: non-toxic and allowing to compete in the hardening speed with CHM on the basis of resin bindings.

From the point of view of regeneration, the practical experience of the core sand mixture composition implementation for the production of cast-iron facing casting indicates 
that the expansion of using bindings with LST increases the regenerative properties of the worked-out mixtures by $12-14 \%$.

The presented examples allow viewing from a new angle the possibilities of lignin containing materials as the potential raw materials for creating new casting bindings in principle [17].

\section{Conclusions}

As a result of the carried out research we found out:

- creating low-toxic bindings on the basis of LST with the properties of highperformance bindings is an effective instrument for solving a complex of problems connected with the increase of resource efficiency of casting processes.

- applying the method of LST mechano-activation leads to the rationalization of the molding sand composition: the decrease of the amount of using "fresh" core sand mixture is possible due to the increase of reclaim part and reduction of molding clay usage by two times. The duration of drying can be reduced by $20-25 \%$, however, for more accurate judgments concerning this issue, additional experimental tests are required.

The study was carried out with the financial support of the Ministry of Education and Science of the Russian Federation within the framework of the scientific project FZEG-2020-0030.

\section{References}

1. A.I. Batyshev, K.A. Batyshev, Foundry engineering 10, 23-27 (2017)

2. M. Holtzer, M. Górny, R. Dańko, Microstructure and properties of ductile iron and compacted graphite iron castings p. 348 (London, Springer (Eds.), 2015)

3. S.S. Zhukovsky Cold-hardening bindings and mixtures for casting rods and moulds: a reference book p. 256 (Moscow: Machine building, 2010)

4. M. Chvojka, L. Mlynarcik, P., Schmiedt Progr. zlievaren. technol. a metalurgii. Konf., Zlata Idka p. 84 (May 29-31, 2009)

5. I.E. Illarionov, Yu.P. Vasin, Moulding materials and mixtures Part 1, p. 223 (Monography, Cheboksary: The publ. house of Chuvash University, 1992)

6. O.V. Rodionov, Yu.S. Svinoroev, et al. Diagnostics of developing the enterprise potential: monography p. 292 (Lugansk: "Knowledge", 2012)

7. Yu. Svinoroev, V. Kostrub, O. Klimova, Teka commission of motorization and power industry in agriculture Lublin university of technology Volodymyr Dal East-Ukrainian national university of Lugansk XB, 227-231 (Lubin, 2010)

8. I.A. Dibrov, The foundry worker of Russia 10, 7-14 (Chelyabinsk, 2017)

9. Forecast: U.S. Casting Sales to Reach \$33 Billion, A Modern Casting Staff Report, Modern Casting 22-27 (2018)

10. The Directive of the European Parliament and Council of the 24-th November 2010 concerning industrial emissions (2010)

11. H. Löfstedt, H. Westberg, A.I. Seldén, I.L. Bryngelsson, M. Svartengren, Journal of Occupational and Environmental Medicine, 53, 1425-1429 (2011)

12. H. Löfstedt, H. Westberg, A.I. Seldén, S. Rudblad, I.L. Bryngelsson, Y. Ngo, M. Svartengren, Journal of Occupational and Environmental Medicine, 53, 43-48 (2011) 
13. The information resource "Hüttenes-Albertus», Germany, access mode: http://www.huettenes-albertus.ru/

14. Yasuyuki Matsushita, J Wood Sci 61, 230-250 (2015)

15. H. Löfstedt, H. Westberg, A.I. Seldén, C. Lundholm, M. Svartengren, American Journal of Industrial Medicine, 52, 455-463 (2009)

16. A.N .Bolding, A.I. Yakovlev, S.D. Teplyakov Engineering ecology of the foundry: a tutorial p. 352 (Ed. by A. N. Boldin, Mscow.: Machine building, 2010)

17. Yu.A. Svinoroev, R. Ber, Yu.I. Gutko, The foundry, 12, 23-26 (2016) 